\title{
Исследования конденсата поляритонов в микрорезонаторных микростолбиках в сильных магнитных полях*
}

\author{
(C) А.В. Черненко ${ }^{1}$, А.С. Бричкин ${ }^{1}$, С.И. Новиков ${ }^{1}$, К. Шнайдер ${ }^{2}$, С. Хёфрлинг ${ }^{2}$ \\ ${ }^{1}$ Институт фризики твердого тела Российской академии наук, \\ 142432 Черноголовка, Московская обл., Россия \\ ${ }^{2}$ Technische Physik, Wilhelm Conrad Roentgen Research Center for Complex Material Systems, \\ Universitat Wuerzburg, Am Hubland, \\ D-97074 Wuerzburg, Germany \\ E-mail: chernen@yandex.ru
}

(Получена 27 апреля 2017 г. Принята к печати 12 мая 2017 г.)

Фотолюминесценция неравновесного конденсата поляритонов в микростолбиках цилиндрической и прямоугольной форм, вытравленных на поверхности высокодобротного микрорезонатора на основе GaAs, исследована в магнитном поле до 12 Тл. Измерения выполнены при различных уровнях нерезонансной импульсной оптической накачки в широком диапазоне значений расстройки резонатора. Нерезонансное возбуждение создает значительную плотность экситонов в резервуаре, что позволяет ожидать существенного влияния экситон-поляритонного взаимодействия, которое зависит от плотности накачки, на величину зеемановского расщепления и поляризацию. Измерения показали лишь незначительное изменение зеемановского расщепления и поляризации в сильных магнитных полях при максимально достижимом уровне накачки; следовательно, влияние экситон-поляритонного взаимодействия на поляритонную систему в нашем случае несущественно. Вместе с тем полученные данные позволили оценить плотность экситонов в резервуаре. В отличие от цилиндрических микростолбиков, фотолюминесценция конденсата из прямоугольных микростолбиков состоит из двух взаимно перпендикулярно линейно поляризованных линий, которые сохраняют высокую степень циркулярной поляризации даже в поле 12 Тл. Зеемановское расщепление в этом случае фактически не зависит от накачки, тогда как степени линейной и циркулярной поляризаций изменяются с накачкой, хотя эти изменения заметно меньше предсказанных теорией. Это указывает на значительное отклонение системы поляритонов в микростолбиках от термодинамически равновесной.

DOI: $10.21883 /$ FTP.2017.12.45172.35

* Полный текст этой статьи будет опубликован в журнале „Физика и техника полупроводников“, том 52 вып. 1. 